\title{
1953 Sask. Conservation Awards
}

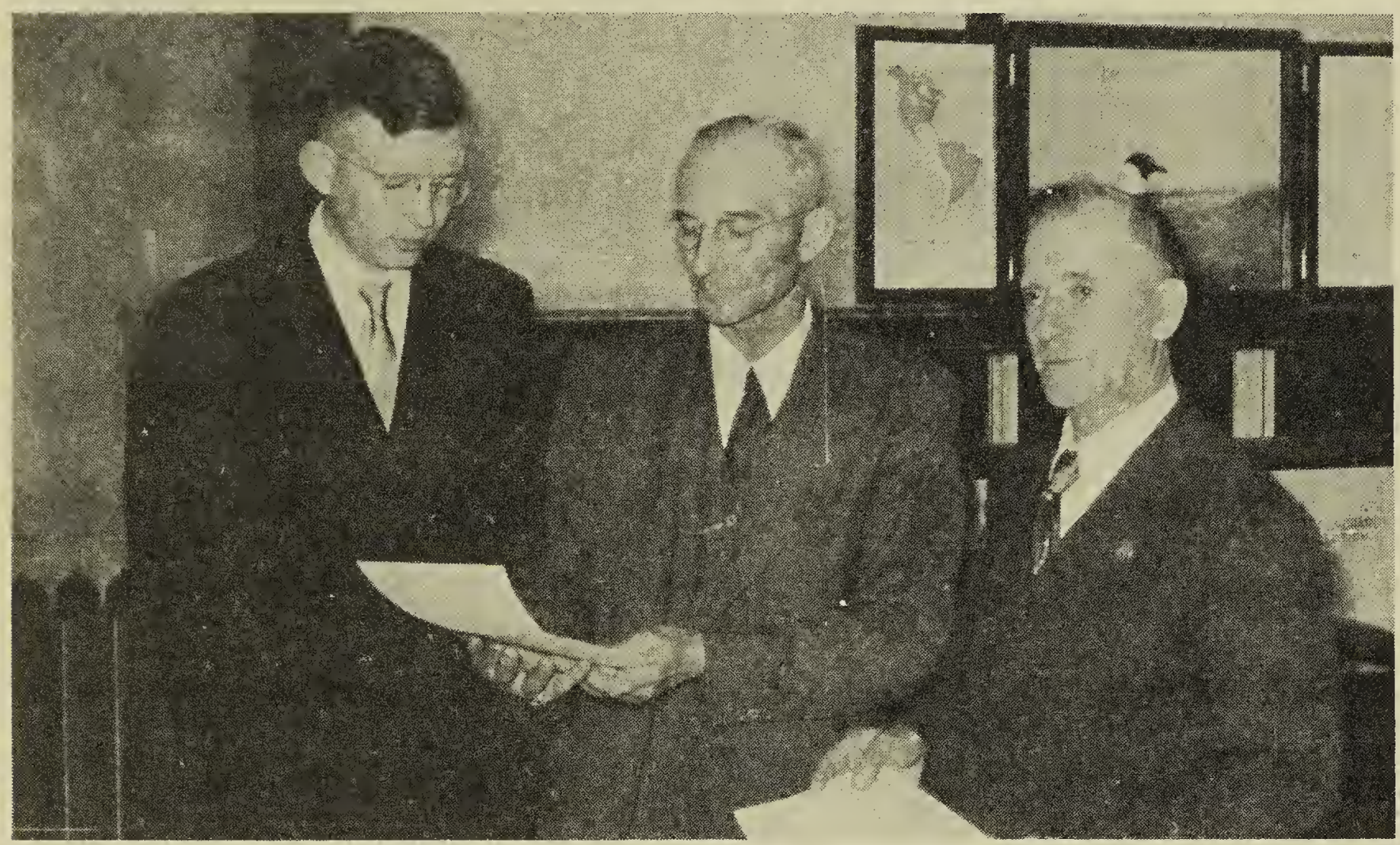

Dr. C. Stuart Houston, Mr. Ralph P. Stueck, Mr. A. C. Budd

At the annual meeting of the Saskatchewan Natural History Society, Ralph Stueck of Abernethy, and A. C. Budd of Swift Current, were presented with the 1953 Saskatchewan Conservation Awards "for meritorious work in the interests of Conservation in Saskatchewan." Mr. Stueck received his award for the conservation education he has done by showing his movies to schools and community organizations throughout the province. He also cared for Queenie, the injured Whooping Crane, when she was flown to Texas last fall. Mr. Budd was honored for the publication of his book, "Plants of the Farming and Ranching Areas of the Prairie Provinces." This book represents years of painstaking work and study, and will be of invaluable assistance to Saskatchewan botanists.

One, and occasionally two, such Conservation Awards will be presented annually for outstanding work in conservation in Saskatchewan. The award will not be made solely for work done for the Saskatchewan Natural History Society, but for work done for conservation in thewider sense.

\section{Quotations from Dr. Martin Fisher}

Dr. Martin Fischer once referred to a conservationist as "that friend of God." I have often pondered this saying. In the goodly company of God's friends, one feels kinship with all living things, and a close relation to the Power from which comes all life. This sense of a Power, this knowledge of a Presence, is strong among naturalists. It is Law to one, Order to another, or Continuity. It is Faith and Hope. Nor can we omit Charity toward all life. Some name this higher sense "the naturalists' religion." But it supersedes no religious faith, it seeks not to undermine any belief, it is not in rivalry with any creed. It is something added to all these. It is an heightening of aspiration, a deepening of understanding, a widening of vision. 